\title{
Geochemical assessment of lake sediments in protected areas in Poland - a search for reference condition
}

\author{
Joanna CIEŚLEWICZ, ${ }^{1 *}$ Mirosław KOBIERSKI, ${ }^{2}$ Marcin $\mathrm{CICHOSZ}^{3}$ \\ ${ }^{1}$ Department of Environmental Chemistry, UTP University of Science and Technology, Bernardyńska 6/8, 85-029 Bydgoszcz; \\ ${ }^{2}$ Department of Soil Science and Soil Protection, UTP University of Science and Technology, Bernardyńska 6/8, 85-029 Bydgoszcz; \\ ${ }^{3}$ Department of Chemical Proecological Processes, Nicolaus Copernicus University, Gagarina 7, 87-100 Toruń, Poland \\ *Corresponding author: joanna@utp.edu.pl
}

\begin{abstract}
This paper presents the results of an assessment of macro- and microelements in the sediments of lakes laying within protected areas in Poland - the Drawa National Park, the Wel Landscape Park and the Górzno-Lidzbark Landscape Park. In each lake two grab sediment sample were collected: one in the littoral zone and the other in the deepest part of the lake basin. Sediment samples analysed for their content of inorganic carbon (IC) and the loss on ignition (LOI at $550^{\circ} \mathrm{C}$ ) and, according to these parameters classified into three sediment types. Micro-elements were detected with SEM-EDX system and the bioavailability of $\mathrm{Zn}, \mathrm{Cu}$, and Fe was evaluated after an extraction with DTPA (diethylenetriaminepentaacetic acid) solution. The most diverse chemical composition of the sediments was observed in the lakes of the Wel Landscape Park Lacustrine sediments were characterized by the heterogeneous content of organic matter (from 11.70 to $52.89 \%$ ), calcium carbonate (from 0.0 to $42.73 \%$ ) and mineral fractions (from 38.24 to $79.46 \%$ ). They consisted of three different types of gyttja (fine grain-size, clayey-calcareous, clayey). The highest content of trace elements was determined in fine grain-size gyttja, which results from their current sorption properties, as well as alimentation by river waters flowing into the lakes. The sediments contained relatively low concentrations of the analysed elements, which was reflected in the low values of the contamination factor $(\mathrm{CF})$, the contamination degree $\left(\mathrm{C}_{\mathrm{deg}}\right)$, the geo-accumulation index $\left(\mathrm{I}_{\text {geo }}\right)$ and the enrichment factor $(\mathrm{EF})$. Values of the $\mathrm{I}_{\text {geo }}$ point out also that these lake sediments were not contaminated by heavy metals. The total content of zinc and copper in some analyzed sediments was higher than the content assumed as acceptable for protected areas. The contribution of bioavailable forms of $\mathrm{Zn}$ and $\mathrm{Cu}$ ranges from 2.3 to $29.1 \%$ for $\mathrm{Zn}$, and from 4.6 to $18.4 \%$ for $\mathrm{Cu}$. The type of sediment, and the surface area largely determined the lake sediment chemical composition, while land-use in the catchments had a minor effect. This applies to both lakes of different parks and lakes within each of the parks.
\end{abstract}

Key words: Lake sediments; geo-accumulation index; enrichment factor, contamination factor.

Received: September 2016. Accepted: June 2017.

\section{INTRODUCTION}

Sediments deposited in lakes constitute a unique record of processes occurring in a given water body and a drainage basin. Changes in the mineral composition of sediments and their content of macro- and micro-elements are important parameters describing the processes occurring in the drainage basin. The chemical composition of the sediments depends mainly on the type of material deposited, the weathering processes and the diagenesis and geochemistry of individual elements (Rollinson, 1993; Solecki and Chibowski, 2000; Mahjoor et al., 2009). The geochemical composition of lacustrine sediments reflects the current state of the environment. Knowledge about the total content of the elements provides important information on the geochemical properties of the sediment (Boyle, 2000; Chabbi, 2003; Sanei et al., 2010).

Trace elements bound in the sediments to organic and mineral colloids settling to the lake bottom where they may adversely affect benthic fauna or macrophytes, which are used in the ecological assessment of aquatic ecosystems (Lewander et al., 1996). In addition, as consequence of resuspension or re-solubilisation process, they can return into circulation in the aquatic ecosystem (Aksoy et al., 2005). They may constitute a threat to biological life in a given ecosystem as a consequence of secondary contamination (Başyiğit and Tekin-Özan, 2013). This process is dependant from the concentration and metal speciation; their mobility is linked to $\mathrm{pH}$ and environmental redox potential (KabataPendias and Pendias, 2001). Geochemical studies have shown the necessity to determine the potentially bioavailable forms of metals as an indicator of their actual toxicity (Głosińska and Siepak, 2006). XRF (X-ray fluorescence spectroscopy) and SEM-EDX (scanning electron microscope - X-ray energy dispersive) analyses are increasingly used in this type of study. Due to the rate of analysis and the possibility of performing the measurements without the initial preparation of samples, the XRF method is extensively applied in monitoring studies. The SEM-EDX method with 
a scanning microscope and an X-ray spectrometer allows for qualitative and quantitative analysis of chemical elements with an atomic number above 5 , with a detection limit for most of the analytes at ca. 0.1\% (Farooqui and Bajpai, 2003; Haley et al., 2006).

The objective of this study was to determine the geochemical heterogeneity of the sediments in lakes situated within the protected areas to identify reference sites for monitoring programme with the aim to detect changes in the environment exposed to strong anthropopressure.

\section{METHODS}

The studied lakes are situated within legally protected areas: the Drawa National Park (DNP), the Wel Landscape Park (WLP) and the Górzno-Lidzbark Landscape Park (GLLP) (Fig. 1). DNP and G-LLP were established in 1990, and WLP in 1995. The parks are located in areas covered by the Vistulian (Weichselian) Glaciation and are characterised by a typical post-glacial relief with outwash plains, moraines, and kames. Lake Grądy and Lake Tarczyńskie have a surface area of over 100 ha and are classified as medium-sized lakes, others as smaller than 50 ha (European Commission, 2000). Thermal stratification does not occur in these lakes due to their limited depth. Piaseczno Małe, Moczel, Jeleń, Linowiec, Czarny Bryńsk closed lakes (no outflow is visible) and they do not have a visible inlet. In Lake Arkońskie and Lake Zwórzno an outflow is visible. Lake Grądy and Lake Tarczyńskie are ribbon lakes, through which flows the Wel River. Basic morphometric data, geographical locations of the studied lakes and their land use in the catchment are presented in Tab. 1.

In all lakes sediment samples were collected in two points: one in the littoral zone and the other in the deepest part of the lake. At each sampling point it was collected sediment layer using an Ekman's grab sampler with the thickness of ca. $20 \mathrm{~cm}$. Sediment samples were air dried, homogenized and then analysed for their content of inorganic carbon (IC) using a Primacs ${ }^{\text {sc }}$ analyser (Skalar, Breda, The Netherlands), and loss on ignition (LOI) at a

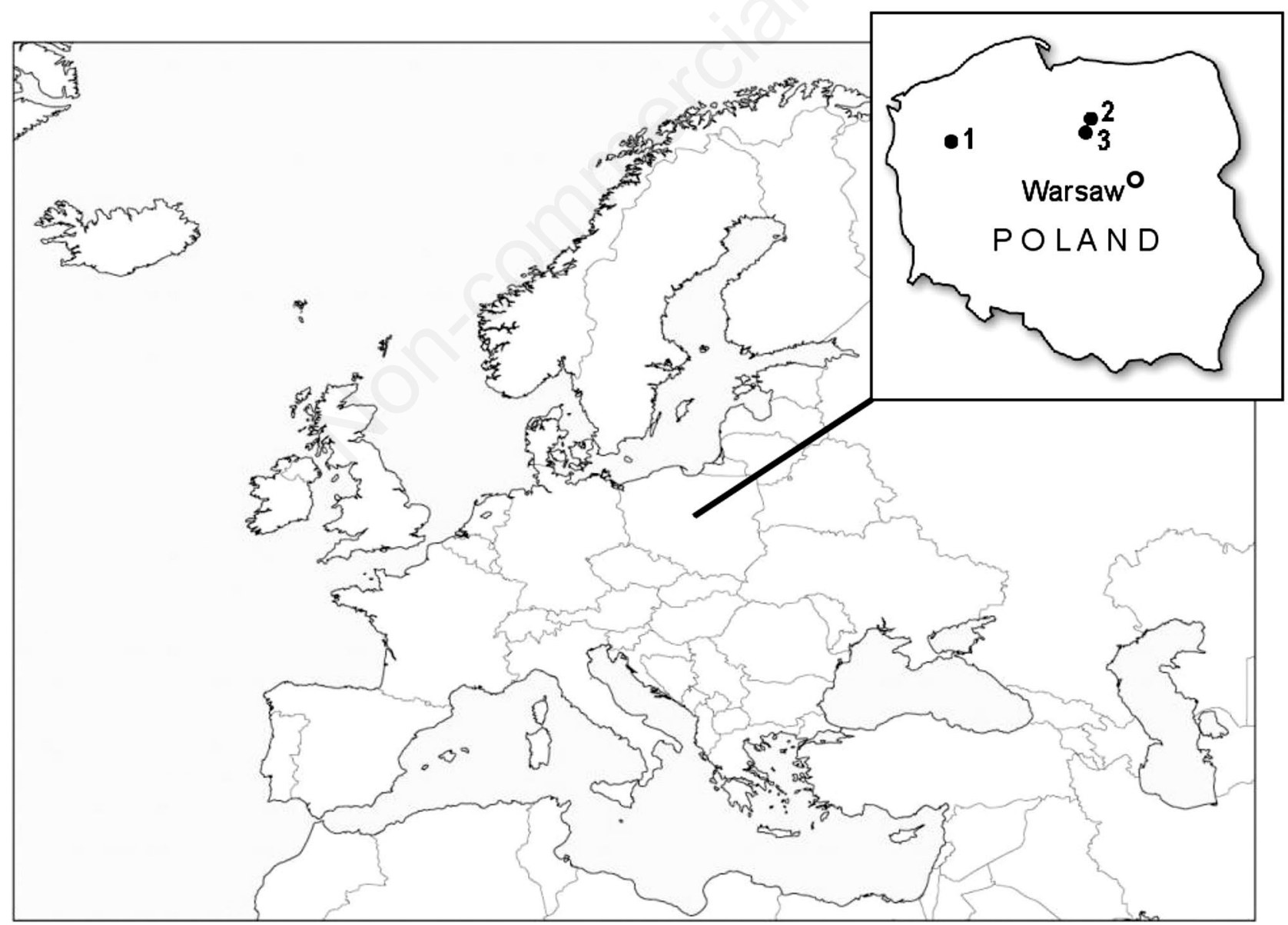

Fig. 1. Geographical position of Poland in Europe and, in the inset, the location of Drawa National Park (1), Wel Landscape Park (2), and Górzno-Lidzbark Landscape Park (3). 
temperature of $550^{\circ} \mathrm{C}$. Based on the percentages of organic matter (LOI), calcium carbonate (IC x 8.33 -conversion of inorganic carbon content on the content of calcium carbonate) and mineral fraction, i.e. non-carbonate fraction, the sediments were classified according to the type and class proposed by Markowski (1980). Macroand microelements were determined in a dry sediment sub-samples with a SEM-EDX (scanning electron microscope - X-ray energy dispersive) system using a LEO Electron Microscopy microscope, model $1430 \mathrm{VP}$, and a Bruker AXS X-ray spectrometer Quantax 200 with a detector XFlash 4010. The reference material consisted of sediments from the Canada Centre for Mineral and Energy Technology, Ottawa, Ontario. The content of the bioavailable forms of $\mathrm{Zn}, \mathrm{Cu}$ and $\mathrm{Fe}$ was analyzed after extraction with the DTPA (diethylenetriaminepentaacetic acid) solution and expressed as percentage respect to the total concentration of these metals (Lindsay and Norvell, 1978). The content of $\mathrm{Zn}, \mathrm{Cu}$ and Fe DTPA-extracted forms was determined by atomic absorption spectrometry (AAS), using a Philips PU $9100 \mathrm{X}$ spectrometer.

There are several classification methods proposed for sediments in water bodies (Macdonald et al., 2000; Burton, 2002; Contaminated Sediment Standing Team, 2003), including the system referred to as LAWA (1998). This method divides the sediments into seven geochemical (purity) classes according to heavy metals content: classes I and I-II is considered as the geochemical background value, while class II or higher denote a progressive increase contamination.

For each metal, it was calculated a values of the contamination factor $(\mathrm{CF})$, the contamination degree $\left(\mathrm{C}_{\mathrm{deg}}\right)$, the geo-accumulation index $\left(\mathrm{I}_{\text {geo }}\right)$ and the enrichment factor (EF). In all the calculations, the average total content of chemical elements in the upper part of the Earth's crust was defined as the geochemical background value (Taylor and McLennan, 1985; Vrhovnik et al., 2013). The CF ex- presses the ratio between the total content of a metal in the sediment and the geochemical background value (Håkanson, 1980). The sum of all CFs expresses the degree of contamination $\left(\mathrm{C}_{\mathrm{deg}}\right)$ in the ecosystem.

To assess the effect of anthropogenic factors on the contamination of sediments with heavy metals, the $\mathrm{I}_{\text {geo }}$ was calculated according to the formula:

$\mathrm{I}_{\text {geo }}=\log _{2}\left(\mathrm{C}_{\mathrm{n}} / 1.5 \mathrm{~B}_{\mathrm{n}}\right)$

where: $\mathrm{C}_{\mathrm{n}}$ is concentration of a metal, $\mathrm{B}_{\mathrm{n}}$ is the mean total content of a chemical element in the upper part of the Earth's crust (geochemical background); and coefficient 1.5 allows for natural lithological variation (Müller, 1969; Rabee et al., 2011; Rabajczyk et al., 2011; Zhang et al., 2012).

The EF was proposed in the 1970s and originally was used to estimate the concentration and origin of some elements in the atmosphere, precipitation and seawater. Later, this index was used for the assessment of contamination in soil, lacustrine and fluvial sediments, and catchments with no soil cover. At present, calculations of the EF values, which reflect the impact of anthropogenic contamination on the content of heavy metals, are performed based on the following formula (Reimann and de Caritat, 2005):

$\mathrm{EF}=\left(\mathrm{C}_{\mathrm{n}} / \mathrm{C}_{\mathrm{nTi}}\right) /\left(\mathrm{B}_{\mathrm{n}} / \mathrm{B}_{\mathrm{nTi}}\right)$

where: $C_{n}$ isthe total content of a metal in an environmental sample, $\mathrm{C}_{\mathrm{nTi}}$ is the total content of Ti as a reference element in an environmental sample, $B_{n}$ is the content of a metal in the geochemical background; $\mathrm{B}_{\mathrm{nTi}}$ is the content of $\mathrm{Ti}$ in the geochemical background.

The most frequently used reference element are: $\mathrm{Ti}$, $\mathrm{Al}, \mathrm{Li}, \mathrm{Sc}, \mathrm{Zr}$. These elements are deemed to be conservative, because they are components of minerals resistant to chemical weathering, and hence they do not actively participate in the geochemical cycles and do not have sig-

Tab. 1. Some morphometric data, geographical locations of the studied lakes and the prevalent land use in their catchment.

\begin{tabular}{|c|c|c|c|c|c|}
\hline Lake and sample symbols & Area (ha) & Maximum depth (m) & Latitude $(\phi)$ & Longitude $(\lambda)$ & Prevalent land use \\
\hline \multicolumn{6}{|c|}{ Drawa National Park } \\
\hline Arkońskie (DR1, DR2) & 13.2 & 3.8 & $53^{\circ} 05^{\prime} 04^{\prime \prime} \mathrm{N}$ & $15^{\circ} 51^{\prime} 07^{\prime \prime} \mathrm{E}$ & Mixed forests \\
\hline Piaseczno Małe (DR3, DR4) & 8.6 & 6.8 & $53^{\circ} 07^{\prime} 43^{\prime \prime} \mathrm{N}$ & $16^{\circ} 00^{\prime} 28^{\prime \prime} \mathrm{E}$ & Mixed forests \\
\hline Moczel (DR5, DR6) & 2.5 & 1.5 & $53^{\circ} 05^{\prime} 05^{\prime \prime} \mathrm{N}$ & $15^{\circ} 53^{\prime} 39^{\prime \prime} \mathrm{E}$ & Deciduous forests \\
\hline \multicolumn{6}{|c|}{ Wel Landscape Park and the buffer zone } \\
\hline Grądy (WL1, WL2) & 112.7 & 9.1 & $53^{\circ} 35^{\prime} 17^{\prime \prime} \mathrm{N}$ & $19^{\circ} 86^{\prime} 44^{\prime \prime} \mathrm{E}$ & Arable lands/forest \\
\hline Tarczyńskie (WL3, WL4) & 163.8 & 9.2 & $53^{\circ} 35^{\prime} 17^{\prime \prime} \mathrm{N}$ & $19^{\circ} 86^{\prime} 44^{\prime \prime} \mathrm{E}$ & Meadows/forests \\
\hline Jeleń (WL5, WL6) & 31.3 & 1.6 & $53^{\circ} 17^{\prime} 51^{\prime \prime} \mathrm{N}$ & $19^{\circ} 51^{\prime} 42{ }^{\prime} \mathrm{E}$ & Arable lands/forest \\
\hline Linowiec (WL7, WL8) & 9.8 & 2.5 & $53^{\circ} 25^{\prime} 30^{\prime \prime} \mathrm{N}$ & $19^{\circ} 43^{\prime} 42^{\prime \prime} \mathrm{E}$ & Arable lands \\
\hline \multicolumn{6}{|c|}{ Górzno-Lidzbark Landscape Park } \\
\hline Czarny Bryńsk (GL1, GL2) & 9.1 & 3.5 & $53^{\circ} 12^{\prime} 35^{\prime \prime} \mathrm{N}$ & $19^{\circ} 43^{\prime} 43^{\prime \prime} \mathrm{E}$ & Mixed forests \\
\hline Zwórzno (GL3, GL4) & 21.1 & 11.6 & $53^{\circ} 14^{\prime} 32^{\prime \prime} \mathrm{N}$ & $19^{\circ} 46^{\prime} 52^{\prime \prime} \mathrm{E}$ & Mixed forests \\
\hline
\end{tabular}

DR1, DR3, DR5, WL1, WL3, WL5, WL7, GL1, GL3, littoral samples; DR2, DR4, DR6, WL2, WL4, WL6, WL8, GL2, GL4, deep samples. 
nificant anthropogenic sources (Li et al., 2001; Sezgin et al., 2003; Duzgoren-Aydin, 2007; Tylmann, 2004). As previously stated, a geochemical background value for each element was defined taking in consideration its mean concentration in the Earth's crust.

For a statistical evaluation of the results, Pearson correlation coefficients using STATISTICA 12.0 software and coefficient of variation (CV) were calculated.

\section{RESULTS}

The results of samples classification based on their organic and inorganic compositions were presented in Tab. 2. Lacustrine sediments were characterized by the heterogeneous content of organic matter ranging from 11.70 to $52.89 \%$. Also, the content of IC was heterogeneous -it ranged from below the detection limit $(<0.1 \%)$ to $42.73 \%$ (per $\mathrm{CaCO}_{3}$ ). The sediment type dominating among the studied lakes is the organic one characterized by a high organic matter content (from 31.06 to $52.89 \%$ ) and the lack of carbonates.

The most diverse macro element composition was observed in the lakes of the Wel Landscape Park (WL; Figs. 2 and 3), which was confirmed by high values of the coefficient of variation (CV; Tab. 3). Sediments form lakes with the largest surface area, i.e. Grądy and Tarczyńskie (WL1, WL2 and WL3, WL4), had the lowest content of silica and aluminium as well as the highest content in calcium. This might be related to the type of sediment and gyttja present in these lakes (Tab. 2). Samples of clayey gyttja collected from Lake Linowiec (WL7, WL8) were characterised by the lowest loss on ignition. Sediment from Lake Linowiec and Lake Jelen (WL5, WL6) had the highest content of potassium. Iron showed the lowest variability among the studied lakes (Fig. 2) with the lowest value in Lake Grądy and Lake Tarczyńskie (WL1, WL2 and WL3, WL4) and Piaseczno Małe Lake (DR3 and DR4).

Magnesium, sodium and potassium, showed the greatest variation and the largest $\mathrm{CV}$ variation (Tab. 3) among the three different Parks area often below the geochemical background value. In addition, aluminium displays a large variability from 3.75 to $22.12 \%$ and was significantly positively correlated with $\mathrm{Si}$ content $(\mathrm{r}=0.59, \mathrm{P}<0.05)$. The total content of calcium in particular sediment samples ranged from 4.11 to $57.73 \%$, which reflects large differences between sediment types (Tab. 2). The content of calcium was significantly negatively correlated with the content of silicate and aluminium, respectively: $r=-0.83$ and $\mathrm{r}=-0.66, \mathrm{P}<0.05$.

In the sediment of studied lakes there were small differences in the concentrations of $\mathrm{Ni}, \mathrm{Pb}$, and $\mathrm{Cu}$. Nickel, lead and copper concentrations were within or slightly exceeded the geochemical background, whereas the content of zinc was, in many cases, higher than the geochemical background value (Tab. 4). Since it is well known that the labile fraction, not only the total concentration of metals is relevant to organism, we have measured also the soluble fraction of some elements. It was found that in all the area

Tab. 2. $\mathrm{pH}$, organic matter, carbonates, mineral composition and their classification according to Markowski (1980) of the studied lakes. The littoral and the deep samples as in Tab. 1.

\begin{tabular}{|c|c|c|c|c|c|c|}
\hline Samples & pH & Organic matter (\%) & $\mathrm{CaCO}_{3}(\%)$ & Carbonate-free mineral fraction ( $\%)$ & Sediment type & Gyttja type \\
\hline \multicolumn{7}{|c|}{ Drawa National Park } \\
\hline DR1 & 5.2 & 48.78 & ND & 51.22 & Organic & Fine grain-size \\
\hline DR2 & 5.2 & 50.25 & ND & 49.75 & Organic & Fine grain-size \\
\hline DR3 & 6.0 & 49.97 & ND & 50.03 & Organic & Fine grain-size \\
\hline DR4 & 5.5 & 48.33 & ND & 51.67 & Organic & Fine grain-size \\
\hline DR5 & 5.2 & 52.89 & ND & 47.11 & Organic & Fine grain-size \\
\hline DR6 & 5.4 & 52.41 & ND & 47.59 & Organic & Fine grain-size \\
\hline \multicolumn{7}{|c|}{ Wel Landscape Park together with the buffer zone } \\
\hline WL1 & 6.4 & 20.61 & 25.07 & 54.32 & Carbonate & Clayey-calcareous \\
\hline WL2 & 6.8 & 18.65 & 40.95 & 40.40 & Carbonate & Clayey-calcareous \\
\hline WL3 & 6.9 & 19.03 & 42.73 & 38.24 & Carbonate & Clayey-calcareous \\
\hline WL4 & 6.2 & 21.06 & 31.80 & 46.60 & Carbonate & Clayey-calcareous \\
\hline WL5 & 5.7 & 31.06 & ND & 68.94 & Organic & Fine grain-size \\
\hline WL6 & 5.4 & 31.22 & ND & 68.78 & Organic & Fine grain-size \\
\hline WL7 & 7.3 & 11.70 & 8.84 & 79.46 & Mineral & Clayey \\
\hline WL8 & 7.3 & 11.75 & 22.36 & 65.89 & Mineral & Clayey \\
\hline \multicolumn{7}{|c|}{ Górzno-Lidzbark Landscape Park } \\
\hline GL1 & 5.9 & 37.51 & ND & 62.49 & Organic & Fine grain-size \\
\hline GL2 & 6.0 & 40.12 & ND & 59.88 & Organic & Fine grain-size \\
\hline GL3 & 7.1 & 20.80 & 3.61 & 75.59 & Mineral & Clayey \\
\hline GL4 & 7.6 & 19.34 & 21.50 & 59.19 & Carbonate & Clayey-calcareous \\
\hline
\end{tabular}

ND, not detected. 
Zinc is the most labile and with little differences across the three area, while larger differences were observed among the different area for copper and iron (Fig. 4).

The $\mathrm{CF}$ and $\mathrm{EF}$, as well as the $\mathrm{I}_{\mathrm{geo}}$ indexes were used to assess the possible contamination from heavy metals and hence give indication about their quality. The $\mathrm{CF}$ values for nickel were lower than 1.0 for all the sediment samples. Values for other elements were much more diverse and they ranged from 0.28 to 1.94 for $\mathrm{Pb}$; from 0.56 to 1.27 for $\mathrm{Cu}$. These results suggest a minor to medium contamination of

Tab. 3. The content of macro-elements (\%) in lake sediments of the studied lakes. The littoral and the deep samples as in Tab. 1.

\begin{tabular}{|c|c|c|c|c|c|c|c|c|c|c|c|}
\hline Samples & $\mathrm{SiO}_{2}$ & $\mathrm{TiO}_{2}$ & $\mathrm{Al}_{2} \mathrm{O}_{3}$ & $\mathrm{Fe}_{2} \mathrm{O}_{3}$ & $\mathrm{MgO}$ & $\mathrm{CaO}$ & $\mathrm{Na}_{2} \mathrm{O}$ & $\mathrm{K}_{2} \mathrm{O}$ & $\mathrm{MnO}$ & $\mathrm{P}_{2} \mathrm{O}_{5}$ & $\mathrm{CO}_{2}$ \\
\hline \multicolumn{12}{|c|}{ Drawa National Park } \\
\hline DR1 & 29.32 & 1.03 & 6.70 & 4.18 & 0.13 & 6.52 & 0.01 & 1.76 & 0.07 & 0.12 & ND \\
\hline DR2 & 27.68 & 0.74 & 8.97 & 2.68 & 1.26 & 5.00 & 0.28 & 1.09 & 0.05 & 0.24 & ND \\
\hline DR3 & 24.28 & 0.41 & 15.32 & 1.56 & 0.04 & 4.81 & 0.02 & 1.47 & 0.13 & 0.15 & ND \\
\hline DR4 & 24.50 & 0.53 & 16.18 & 1.66 & 0.04 & 4.87 & 0.01 & 1.54 & 0.05 & 0.15 & ND \\
\hline DR5 & 25.96 & 0.56 & 10.19 & 2.87 & 0.45 & 6.15 & 0.15 & 0.45 & 0.04 & 0.18 & ND \\
\hline DR6 & 27.80 & 0.57 & 10.24 & 2.72 & 0.54 & 5.01 & 0.06 & 0.32 & 0.06 & 0.19 & ND \\
\hline CV (\%) & 7.6 & 34.1 & 33.0 & 36.5 & 114 & 13.8 & 122 & 54.3 & 49.0 & 24.3 & - \\
\hline \multicolumn{12}{|c|}{ Wel Landscape Park with the buffer zone } \\
\hline WL1 & 3.92 & 0.43 & 3.75 & 1.30 & 0.28 & 57.73 & 0.02 & 0.13 & 0.09 & 0.24 & 11.03 \\
\hline WL2 & 3.99 & 0.44 & 3.84 & 1.36 & 0.29 & 51.67 & 0.02 & 0.15 & 0.08 & 0.03 & 18.02 \\
\hline WL3 & 4.17 & 0.60 & 3.91 & 1.91 & 0.04 & 52.11 & 0.02 & 0.19 & 0.09 & 0.01 & 17.98 \\
\hline WL4 & 12.33 & 0.40 & 3.52 & 1.72 & 0.18 & 45.65 & 0.02 & 0.32 & 0.11 & 0.02 & 13.99 \\
\hline WL5 & 43.36 & 0.78 & 11.62 & 4.53 & 0.27 & 6.74 & 0.25 & 3.75 & 0.04 & 0.2 & ND \\
\hline WL6 & 39.38 & 0.95 & 13.10 & 5.72 & 0.31 & 4.11 & 0.20 & 4.13 & 0.05 & 0.2 & ND \\
\hline WL7 & 40.72 & 0.93 & 13.66 & 7.35 & 1.57 & 15.20 & 0.64 & 4.11 & 0.10 & 0.19 & 3.89 \\
\hline WL8 & 39.85 & 0.89 & 16.72 & 2.94 & 1.53 & 14.22 & 0.39 & 2.94 & 0.19 & 0.16 & 7.84 \\
\hline CV $(\%)$ & 80.1 & 35.0 & 63.2 & 67.7 & 111 & 73.8 & 117 & 98.0 & 48.7 & 72.2 & 81.1 \\
\hline \multicolumn{12}{|c|}{ Górzno-Lidzbark Landscape Park } \\
\hline GL1 & 26.30 & 0.88 & 22.12 & 2.43 & 0.23 & 8.59 & 0.06 & 1.26 & 0.03 & 0.15 & ND \\
\hline GL2 & 24.38 & 1.31 & 18.75 & 3.09 & 0.20 & 9.34 & 0.17 & 1.74 & 0.03 & 0.19 & ND \\
\hline GL3 & 17.32 & 0.72 & 14.45 & 4.53 & 0.37 & 39.18 & 0.09 & 0.77 & 0.05 & 0.06 & 1.59 \\
\hline GL4 & 16.11 & 0.95 & 7.25 & 3.29 & 1.56 & 39.71 & 0.29 & 0.32 & 0.13 & 0.15 & 9.46 \\
\hline CV (\%) & 24.1 & 25.8 & 41.0 & 26.3 & 110 & 72.7 & 67.4 & 60.0 & 79.3 & 40.0 & 164 \\
\hline
\end{tabular}

CV, coefficient of variation; $N D$, not detected.

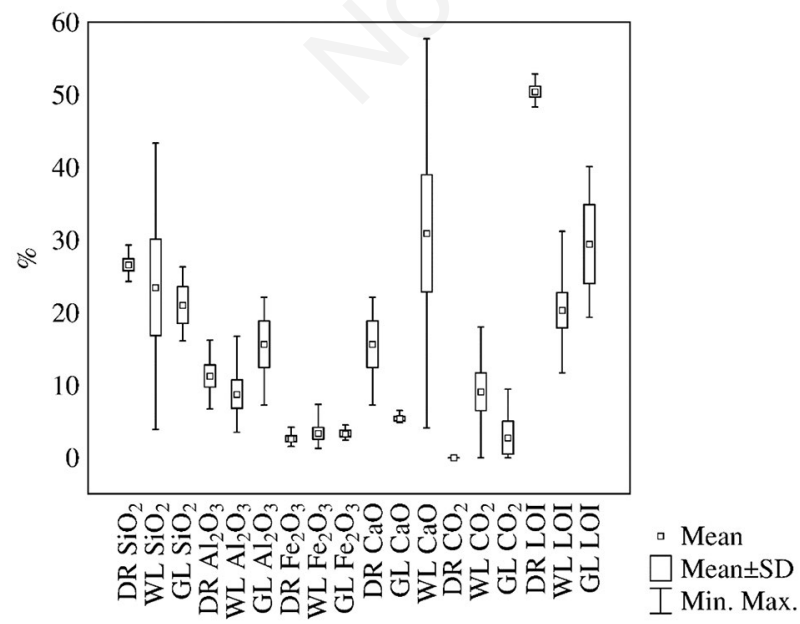

Fig. 2. Total content of elements and loss-on-ignition (LOI) in lake sediments. DR, samples from Drawa National Park; WL, Wel Landscape Park with the buffer zone; GL, Górzno-Lidzbark Landscape Park; SD, standard deviation.

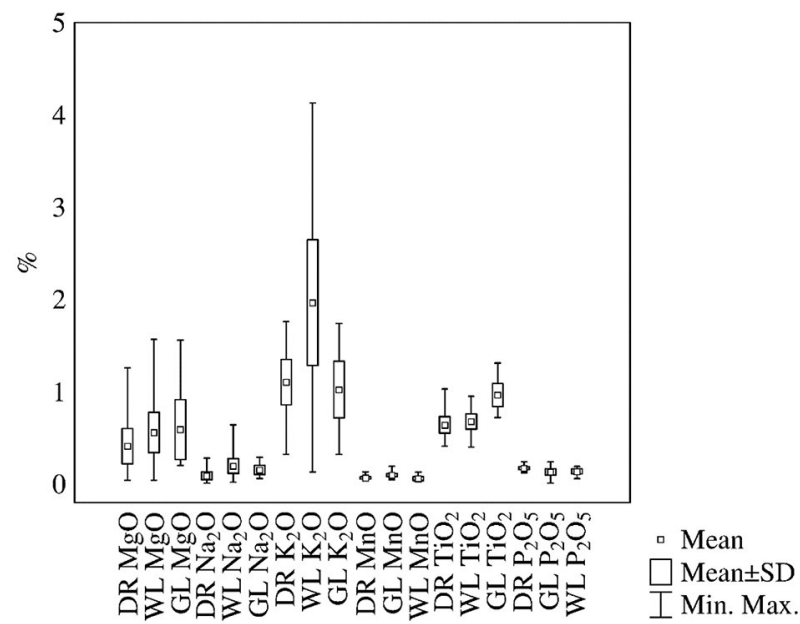

Fig. 3. Total content of elements in lake sediments. DR, samples from Drawa National Park; WL, Wel Landscape Park with the buffer zone; GL, Górzno-Lidzbark Landscape Park; SD, standard deviation. 
the sediment. Much higher CF values were obtained for zinc and they ranged from 0.49 to 3.92 (Fig. 5).

Values of the $I_{\text {geo }}$ point out also that these lake sediments were not contaminated by heavy metals (Tab. 5). The highest $I_{\text {geo }}$ values were obtained for zinc with a range between -1.11 and 0.96 . The EF was used to estimate the contamination of sediments and to discriminate the con- tamination sources resulting from natural processes or anthropogenic impact. As indicated by relatively low EF values (Tab. 5), the sediments are not enriched with the analysed trace elements. The EF for sediments from Lake Piaseczno Małe exceeded the value of 2.0 for lead (sample DR3) and zinc (sample DR4), which proves a slight enrichment of these metals in the sediments.

Tab. 4. The content of micro-elements and the sediment quality classes according to LAWA classification (LAWA, 1998) in the studied lakes. The littoral and the deep samples as in Tab. 1.

\begin{tabular}{|c|c|c|c|c|c|c|c|c|}
\hline Samples & $\begin{array}{c}\mathrm{Ni} \\
\left(\mathrm{mg} \mathrm{kg}^{-1}\right)\end{array}$ & (class) & $\begin{array}{c}\mathrm{Pb} \\
\left(\mathrm{mg} \mathrm{kg}^{-1}\right)\end{array}$ & (class) & $\begin{array}{c}\mathrm{Zn} \\
\left(\mathrm{mg} \mathrm{kg}^{-1}\right)\end{array}$ & (class) & $\begin{array}{c}\mathrm{Cu} \\
\left(\mathrm{mg} \mathrm{kg}^{-1}\right)\end{array}$ & (class) \\
\hline \multicolumn{9}{|c|}{ Drawa National Park } \\
\hline DR1 & 5.40 & (I) & 11.3 & (I) & 117.8 & (I-II) & 21.2 & (I-II) \\
\hline DR2 & 6.30 & (I) & 15.6 & (I) & 147.5 & (I-II) & 31.3 & (I-II) \\
\hline DR3 & 4.80 & (I) & 38.8 & (I-II) & 98.0 & (I) & 27.2 & (I-II) \\
\hline DR4 & 11.3 & (I) & 21.5 & (I) & 166.6 & (I-II) & 25.2 & (I-II) \\
\hline DR5 & 8.80 & (I) & 24.3 & (I) & 138.4 & (I-II) & 18.6 & (I) \\
\hline DR6 & 7.10 & (I) & 9.80 & (I) & 100.8 & (I-II) & 16.0 & (I) \\
\hline \multicolumn{9}{|c|}{ Wel Landscape Park with the buffer zone } \\
\hline WL1 & 9.00 & (I) & 7.80 & (I) & 36.1 & (I) & 15.1 & (I) \\
\hline WL2 & 10.7 & (I) & 10.1 & (I) & 35.1 & (I) & 14.7 & (I) \\
\hline WL3 & 15.3 & (I) & 8.60 & (I) & 45.8 & (I) & 14.1 & (I) \\
\hline WL4 & 10.5 & (I) & 11.2 & (I) & 46.4 & (I) & 17.3 & (I) \\
\hline WL5 & 10.2 & (I) & 10.8 & (I) & 116.7 & (I-II) & 19.0 & (I) \\
\hline WL6 & 6.30 & (I) & 21.1 & (I) & 235.3 & (II) & 31.7 & (I-II) \\
\hline WL7 & 5.60 & (I) & 15.6 & (I) & 97.4 & (I) & 24.7 & (I-II) \\
\hline WL8 & 6.90 & (I) & 17.5 & (I) & 112.1 & (I-II) & 26.5 & (I-II) \\
\hline \multicolumn{9}{|c|}{ Górzno-Lidzbark Landscape Park } \\
\hline GL1 & 7.10 & (I) & 5.60 & (I) & 99.5 & (I) & 14.4 & (I) \\
\hline GL2 & 5.50 & (I) & 24.9 & (I) & 278.2 & (II) & 21.4 & (I-II) \\
\hline GL3 & 8.40 & (I) & 22.3 & (I) & 46.8 & (I) & 14.7 & (I) \\
\hline GL4 & 4.60 & (I) & 10.8 & (I) & 129.1 & (I-II) & 18.1 & (I) \\
\hline
\end{tabular}

Classes according to LAWA (mg $\left.\mathrm{kg}^{-1}\right)$ : class I, $\leq 30$; class I, $\leq 25$; class I, $\leq 100$; class $I$-II $\leq 60$; class I-II, $\leq 60$; class I-II, $\leq 50$; class I-II, $\leq 200$; class I-II, $\leq 40$; class II, $\leq 400$; class II, $\leq 100$; class II, $\leq 400$; class II, $\leq 80$; Class I, not contaminated; Class I-II, Class I-II, not contaminated / moderately contaminated; Class II, moderately contaminated.

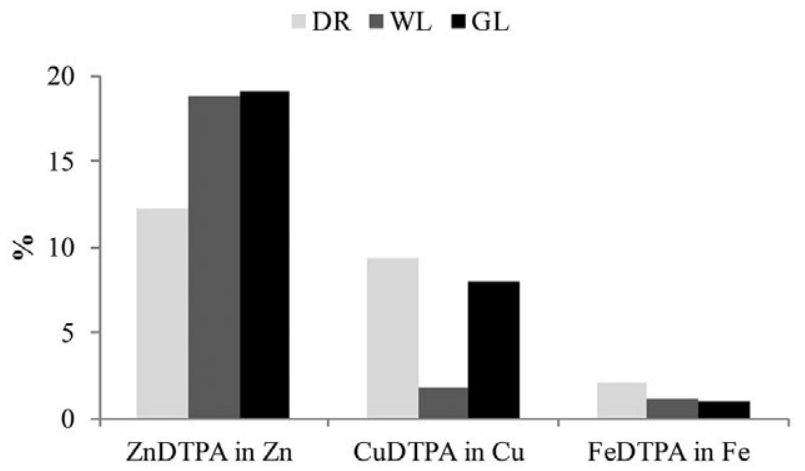

Fig. 4. The percentage contribution of the DTPA-extracted forms to the total content of elements. DR, samples from Drawa National Park; WL, Wel Landscape Park with the buffer zone; GL, Górzno-Lidzbark Landscape Park; SD, standard deviation.

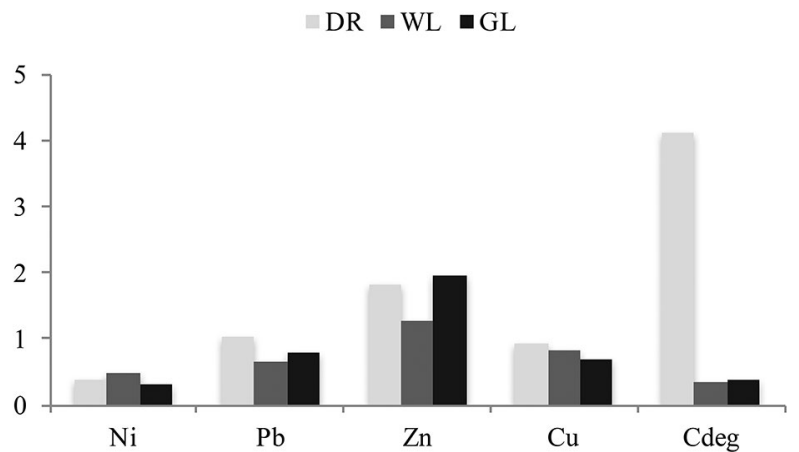

Fig. 5. Mean values of the contamination factor $(\mathrm{CF})$ and the contamination degree $\left(\mathrm{C}_{\mathrm{deg}}\right)$. DR, samples from Drawa National Park; WL, Wel Landscape Park with the buffer zone; GL, Górzno-Lidzbark Landscape Park; SD, standard deviation. 


\section{DISCUSSION}

The most diverse chemical composition of the sediments was observed in the lakes of the Wel Landscape Park (WL). Sediments of the lakes with the largest surface (Lake Grądy and Lake Tarczyńskie) area had the lowest content of silica and aluminium as well as the highest total content of calcium. This should also be related to the type of sediment and gyttja (clayey-calcareous gyttja) present in the lakes. Sediment samples from Lake Linowiec and Lake Jeleń had the highest total content of potassium, which should be associated with the presence of primary and clay minerals rich in potassium (Warren et al., 1996). The type of minerals found in these sediments samples are derived from a variety of materials, which reflect the glacial and postglacial history of the lakes. This metal is found in association with soil particles and thus its presence indicates changes in soil erosion rates in the watershed. Titanium-containing minerals are resistant to weathering, and therefore they are used to assess the origin of the mineral fraction of the sediment. Titanium as a conservative lithogenic element is also used to study anthropogenic element enrichments in lake sediments (Boës et al., 2011). Sediments collected from the surveyed lakes had a relatively similar total content of iron. Iron as a conservative tracer is often used to differentiate natural from anthropogenic components of bulk sediment metal concentrations. The content of iron and manganese in the sediments of lakes depends on the genesis of these sediments and redox processes determining the chemistry of these metals (Nealson and Saffarini, 1993; Naeher et al., 2013), which usually are not subject to anthropogenic accumulation. Their redox-sensitive behaviour in aquatic environments is dependent on the processes of oxidation and reduction of the pairs $\mathrm{Fe}(\mathrm{II}) / \mathrm{Fe}(\mathrm{III})$ and $\mathrm{Mn}(\mathrm{II}) / \mathrm{Mn}$ (IV), which result either in precipitation or (re)dissolution. Especially in lakes, seasonal redox changes in the hypolimnion result in the cycling of $\mathrm{Fe}$ and $\mathrm{Mn}$. Both metals have soluble reduced forms and insoluble oxyhydroxides which are readily interconverted in the vicinity of a redox boundary (Davison, 1993). Lead and zinc had a similar trend with organic matter, but the correlations were not statistically significant. Aluminium showed a large variability among the studied lakes probably as a consequence of accumulation of alumina-silicate minerals transported with suspended matter and enrichment due to weathering process. The acid reaction of soils in the surrounding areas of some lakes is the cause of aluminium release from the structures of primary and secondary minerals. In water ecosystems with $\mathrm{pH}$ ranging from 5.0 to 8.5 (Gensemer and Playle, 1999), the dissolved aluminium compounds are hydrolysed to form solid, amorphous $\mathrm{Al}(\mathrm{OH})_{3}$ and $\mathrm{H}^{+}$, which leads to a subsequent $\mathrm{pH}$ reduction. Aluminium hydroxide binds to phosphorus in the sediment regardless of redox conditions. Content of $\mathrm{Al}(\mathrm{OH})_{3}$ has a high affinity with inorganic and organic phosphorus (Kennedy and Cook, 1982; Reitzel et al., 2005, 2009, 2013). Calcium compounds in natural waters are among the most common alkaline earth metals. Their concentration in the

Tab. 5. Values of the geo-accumulation index $\left(\mathrm{I}_{\text {geo }}\right)$ and the enrichment factor $(\mathrm{EF})$ in the studied lakes. The littoral and the deep samples as in Tab. 1.

\begin{tabular}{|c|c|c|c|c|c|c|c|c|}
\hline \multirow[t]{2}{*}{ Samples } & \multicolumn{4}{|c|}{$\mathbf{I}_{\text {geo }}$} & \multicolumn{4}{|c|}{ EF } \\
\hline & $\mathrm{Ni}$ & $\mathrm{Pb}$ & $\mathrm{Zn}$ & $\mathrm{Cu}$ & $\mathrm{Ni}$ & $\mathrm{Pb}$ & $\mathrm{Zn}$ & $\mathrm{Cu}$ \\
\hline \multicolumn{9}{|c|}{ Drawa National Park } \\
\hline DR1 & -1.71 & -0.98 & 0.10 & -0.57 & 0.13 & 0.27 & 0.81 & 0.41 \\
\hline DR2 & -1.56 & -0.65 & 0.33 & -0.18 & 0.21 & 0.53 & 1.40 & 0.85 \\
\hline DR3 & -1.83 & 0.26 & -0.08 & -0.32 & 0.29 & 2.37 & 1.68 & 1.33 \\
\hline DR4 & -0.98 & -0.33 & 0.45 & -0.40 & 0.53 & 1.01 & 2.22 & 0.95 \\
\hline DR5 & -1.23 & -0.21 & 0.26 & -0.70 & 0.39 & 1.09 & 1.74 & 0.66 \\
\hline DR6 & -1.44 & -1.12 & -0.06 & -0.85 & 0.31 & 0.43 & 1.25 & 0.56 \\
\hline \multicolumn{9}{|c|}{ Wel Landscape Park with the buffer zone } \\
\hline WL1 & -1.20 & -1.35 & -1.08 & -0.91 & 0.52 & 0.45 & 0.59 & 0.70 \\
\hline WL2 & -1.03 & -1.09 & -1.11 & -0.94 & 0.61 & 0.57 & 0.56 & 0.67 \\
\hline WL3 & -0.67 & -1.25 & -0.84 & -0.98 & 0.64 & 0.36 & 0.54 & 0.47 \\
\hline WL4 & -1.05 & -0.99 & -0.83 & -0.77 & 0.66 & 0.70 & 0.82 & 0.87 \\
\hline WL5 & -1.08 & -1.02 & 0.09 & -0.68 & 0.33 & 0.35 & 1.05 & 0.49 \\
\hline WL6 & -1.56 & -0.35 & 0.79 & -0.17 & 0.17 & 0.56 & 1.75 & 0.67 \\
\hline WL7 & -1.68 & -0.65 & -0.09 & -0.42 & 0.15 & 0.42 & 0.74 & 0.53 \\
\hline WL8 & -1.47 & -0.54 & 0.05 & -0.35 & 0.19 & 0.49 & 0.89 & 0.60 \\
\hline \multicolumn{9}{|c|}{ Górzno-Lidzbark Landscape Park } \\
\hline GL1 & -1.44 & -1.68 & -0.07 & -0.96 & 0.20 & 0.16 & 0.80 & 0.33 \\
\hline GL2 & -1.70 & -0.19 & 0.96 & -0.56 & 0.11 & 0.48 & 1.50 & 0.33 \\
\hline GL3 & -1.27 & -0.30 & -0.82 & -0.94 & 0.29 & 0.77 & 0.46 & 0.41 \\
\hline GL4 & -1.88 & -1.02 & 0.19 & -0.73 & 0.12 & 0.28 & 0.96 & 0.38 \\
\hline
\end{tabular}


lake and river waters is affected by the drainage basin geology, the type of land development, as well as the processes occurring in the pelagic zone. Calcium compounds present in the water are derived mainly from dissolution of soil minerals containing calcium. Acid rains contribute to leaching of calcium from the soil. Whereas calcium from fertilizers is a significant source in areas used mainly for agriculture. Calcium carbonate (calcite) present in the lake sediments may occur due to the assimilation activity of aquatic plants (both algae and macrophytes) from calcium bicarbonate present in the water (Wetzel, 1983). Also calcified exoskeletons of animals are a possible source of calcium carbonate in the sediments. The differences in the calcium content resulted associated with the type of catchment bedrock. Sediments of lakes, whose surroundings are dominated by coniferous forests, are characterized by the low $\mathrm{pH}$ values of water and sediments, which prevents accumulation of calcium in the form of calcium carbonate. The examined sediments were characterized by relatively low but heterogeneous content of potassium and sodium in particular lakes, often below the geochemical background value. The obtained content values were similar or lower compared to values obtained for sediments of similar character (Håkanson, 1980; Calanchi et al., 1996; Das and Haake, 2003; Kumar et al., 2009). Tab. 6 presents the geochemical background value (Taylor and McLennan, 1985) and the content of macroelements in sediment samples collected from several lakes (Calanchi et al., 1996; Das and Haake, 2003), including those located in protected areas.

Among lakes here considered there were small differences in the concentrations of $\mathrm{Ni}, \mathrm{Pb}$, and $\mathrm{Cu}$. Nickel, lead and copper concentrations and their values were within or slightly exceeded the geochemical background. The only exception is $\mathrm{Zn}$ that often shows concentration higher than the geochemical background. The relatively high total content of zinc was observed in samples characterised by the high content of organic matter. The mobility of metals is mostly affected by the content of organic matter, texture, mineral composition, sorption capacity, $\mathrm{pH}$ and redox potential (Kabata-Pendias and Pendias, 2001; Harmsen, 2007). Based on the analysis of the research results, it has been found that the content of nickel, lead and copper was within the range of class I and I- II (LAWA, 1998), which point out to a not contaminated and moderately contaminated sediments. Tab. 7 presents a comparison between the trace elements concentration obtained in this study with data present in literature. Based on these comparison, it is evident that the content of chemical elements in the analysed sediments varied within very wide ranges. Due to the complexity of the mechanisms that governs the fate of trace elements in lake sediments, it is very difficult to interpret these results. Anthropogenic heavy metals deposited into sediments and soils as a result of human activities are more mobile than lithogenic and pedogenic metals the origins of which are difficult to distinguish (Kabata-Pendias, 2004).

The content of the elements in the forms available for plants is important in terms of the biological life in a lake. The total content of zinc in some sediments was higher than the content assumed as acceptable for protected areas. It was found that the sediments did not differ in the content of zinc extracted with DTPA solution, whereas they differed in the content of copper and iron forms. The content of copper extracted with DTPA solution did not exceed the content defined as the geochemical background for the surface layer of the Earth's crust, that is, $25 \mathrm{mg} \mathrm{kg}^{-1}$ (Taylor and McLennan, 1985), and the content accepted for lacustrine sediments in Poland, that is $6 \mathrm{mg}$ $\mathrm{kg}^{-1}$ (Bojakowska and Sokołowska, 1998). The average content of zinc in sediment samples collected from 260 lakes in Greater Poland, Pomerania and Masurian Lakelands was $93.0 \mathrm{mg} \mathrm{kg}^{-1}$ (Bojakowska et al., 2014).

The CF and EF, as well as the $\mathrm{I}_{\text {geo }}$ were used to describe the concentration of trace elements in sediments of the studied lakes in order to assess their quality. Values of the calculated factor indicate minor $(\mathrm{CF}<1)$ and medium $(1<\mathrm{CF}$ $<3$ ) contamination. Much higher $\mathrm{CF}$ values were obtained for zinc indicated major contamination. The degree of contamination, defined on the basis of $\mathrm{CF}$ values, did not exceed the value of 8 for any of the analysed samples, which indicates low contamination of the examined sediments (Fig. 5). Values of the $\mathrm{I}_{\text {geo }}$ indicate also that the sediments of the studied lakes were not contaminated with heavy metals (Tab. 5). The highest $I_{\text {geo }}$ values were obtained for zinc; values of the index ranged for this metal from -1.11 to 0.96 , which classified the sediments into class 0 or class 1 (basically uncontaminated - uncontaminated or moderately contaminated). The EF was used to assess the contamination of sediments and to identify the contamination sources resulting from natural processes or anthropogenic impact. As indicated by relatively low EF values (Tab. 5), the sediments are not enriched with the analysed trace elements. The EF for sediments from Lake Piaseczno Małe exceeded the value of 2.0 for lead (sample DR3), as well as for zinc (sample DR4), which proves slight enrichment of sediments with these metals. With regard to soil material, values below 5.0 are not recognized as significant, because so small an enrichment may result from local differences in the mineral composition of the analysed soils (Sezgin et al., 2003).

\section{CONCLUSIONS}

The research involved sediments of lakes situated in the protected areas in Poland. They consisted of three different types of sediment, defined on the basis of the content of organic matter, calcium carbonate and mineral fractions.

Sediments collected from the surveyed lakes had a similar total content of iron and titanium, whereas differed 
in the total content of $\mathrm{Al}, \mathrm{Mg}, \mathrm{K}$ and $\mathrm{Na}$. No differences were found in trace elements concentrations. Nickel, lead and copper concentrations were within or slightly exceeded the geochemical background. The content of zinc was, in many cases, higher than the geochemical background value. Sediments with the highest content of these metals were characterized by a high content of organic matter. The total content of $\mathrm{Zn}$ and $\mathrm{Cu}$ in some sediments was higher than the content assumed as acceptable for protected areas. The contribution of bioavailable forms of zinc and copper (extracted with DTPA) ranges from 2.3 to $29.1 \%$ for $\mathrm{Zn}$, and from 4.6 to $18.4 \%$ for $\mathrm{Cu}$. The highest content of the analysed trace elements was determined in fine grain-size gyttja, which results from their current sorption properties, as well as alimentation by river waters flowing into the studied lakes. Sediments of the studied lakes located in the zone of protected areas may provide reference material for monitoring studies and may consti-

Tab. 6. Comparison of the macroelements' content in the lacustrine sediments.

\begin{tabular}{llcccc} 
Parameter & & This study & (Taylor and McLennan, 1985) & (Calanchi et al., 1996) & (Das and Haake, 2003) \\
$\mathrm{SiO}_{2}$ & $(\%)$ & $3.92-39.85$ & 65.89 & $27.68-52.96$ & $55.03-73.11$ \\
\hline $\mathrm{TiO}_{2}$ & $(\%)$ & $0.40-1.31$ & 0.50 & $0.10-0.80$ & $0.38-0.65$ \\
\hline $\mathrm{Al}_{2} \mathrm{O}_{3}$ & $(\%)$ & $3.52-22.12$ & 15.17 & $2.79-15.31$ & $9.44-19.11$ \\
\hline $\mathrm{Fe}_{2} \mathrm{O}_{3}$ & $(\%)$ & $1.30-7.35$ & - & $1.06-8.06$ & $2.58-6.07$ \\
\hline $\mathrm{MgO}$ & $(\%)$ & $0.04-1.57$ & 2.20 & $0.51-5.45$ & $1.22-1.87$ \\
\hline $\mathrm{CaO}$ & $(\%)$ & $4.11-57.73$ & 4.19 & $0.98-33.26$ & $0.26-1.44$ \\
\hline $\mathrm{Na}_{2} \mathrm{O}$ & $(\%)$ & $0.01-0.64$ & 3.89 & $0.18-2.29$ & $0.45-0.62$ \\
\hline $\mathrm{K}_{2} \mathrm{O}$ & $(\%)$ & $0.13-4.13$ & 3.39 & $0.48-5.99$ & $1.73-3.35$ \\
\hline $\mathrm{MnO}$ & $(\%)$ & $0.03-0.19$ & 0.07 & $0.02-0.43$ & $0.04-0.08$ \\
\hline $\mathrm{P}_{2} \mathrm{O}_{5}$ & $(\%)$ & $0.01-0.24$ & 0.20 & $0.10-0.86$ & $0.09-0.20$ \\
\hline
\end{tabular}

Tab. 7. Range of concentrations of some trace elements in lacustrine sediments compared with the result obtained in this study. The littoral and the deep samples as in Tab. 1.

\begin{tabular}{|c|c|c|c|c|}
\hline $\mathrm{Ni}$ & $\mathrm{Pb}$ & $\mathrm{Zn}$ & $\mathrm{Cu}$ & Source \\
\hline $4.60-15.3$ & $5.60-38.8$ & $35.1-278.2$ & $14.1-31.7$ & This study \\
\hline- & $12-20$ & $68-92$ & $43-51$ & (Domagalski et al., 1990) \\
\hline $83-85$ & $125-133$ & $394-419$ & $105-113$ & (Mudroch, 1993) \\
\hline $7-39$ & $3-47$ & $26-87$ & n.d. -128 & (Calanchi et al., 1996) \\
\hline $1.60-2.95$ & $9.7-13.4$ & - & $2.05-2.95$ & (Szymanowska et al., 1999) \\
\hline- & $32-81$ & $60-126$ & $26-36$ & (Solecki and Chibowski, 2000) \\
\hline 21.2 & 7.97 & 24.7 & 21.4 & (Tokalioğlu et al., 2000) \\
\hline $25-55$ & - & $61-353$ & $19-42$ & (Das and Haake, 2003) \\
\hline- & $13.6 \pm 4.2$ & $37.4 \pm 5.1$ & $13.9 \pm 3.8$ & (Lepane et al., 2007) \\
\hline $29-71$ & $16.4-126$ & $70-545$ & $33-266$ & (Poté et al., 2008) \\
\hline $29.99 \pm 8.4$ & $2.44 \pm 2.2$ & - & $29.98 \pm 4.7$ & (Öztürk et al., 2009) \\
\hline \multirow[t]{2}{*}{$2.9-28.3$} & $2.7-70.0$ & $35.2-189.8$ & $3.0-32.4$ & (Tylmann et al., 2011) \\
\hline & $47.2-291$ & $9.7-68$ & $1.2-2.8$ & (Rabajczyk et al., 2011) \\
\hline $62.5 \pm 26.5$ & $32.71 \pm 16.94$ & $42.39 \pm 17.95$ & $1.52 \pm 0.87$ & (Njogu et al., 2011) \\
\hline $12.04-63.49$ & $23.35-496.75$ & $34.64-872.13$ & $0.00-388.85$ & (Leopold et al., 2012) \\
\hline- & $27.69-58.71$ & $352.88-391.21$ & $158.52-229.25$ & (Ntakirutimana et al., 2013) \\
\hline 27.56 & 10.91 & 35.38 & 21.78 & (Goher et al., 2014) \\
\hline $60.5 \pm 21.6$ & $61.9 \pm 36.0$ & $192 \pm 120$ & $54.7 \pm 29.1$ & (Tang et al., 2014) \\
\hline $22.20-91.05$ & $10.42-29.82$ & $13.06-102.5$ & $4.11-79.23$ & (El-Sayed et al., 2015) \\
\hline $0.0-16.0$ & $8.2-292.0$ & $21.0-901.0$ & $2.2-126.0$ & (Juśkiewicz et al., 2015) \\
\hline
\end{tabular}


tute an important element in the environmental assessment of areas exposed to anthropic pressure.

\section{ACKNOWLEDGMENTS}

We are grateful to respected Prof. Janusz Hermann Director of Department of Environmental Chemistry, UTP University of Science and Technology in Bydgoszcz for permitting us to utilize all the necessary facilities of the institution. We are also thankful to all the other faculty and staff members of our departments for their kind cooperation and help.

\section{REFERENCES}

Aksoy A, Demirezen D, Duman F, 2005. Bioaccumulation, detection and analyses of heavy metal pollution in Sultan Marsh and its environment. Water Air Soil Poll. 164:241-255.

Başyiğit B, Tekin-Özan S, 2013. Concentrations of some heavy metals in water, sediment, and tissues of pikeperch (Sander lucioperca) from Karataş Lake related to physico-chemical parameters, fish size and seasons. Pol. J. Environ. Stud. 22:633-644.

Boës X, Rydberg J, Martinez-Cortizas A, Bindler R, Renberg I, 2011. Evaluation of conservative lithogenic elements (Ti, $\mathrm{Zr}, \mathrm{Al}$, and $\mathrm{Rb}$ ) to study anthropogenic element enrichments in lake sediments. J. Paleol. 46:75-87.

Bojakowska I, Sokołowska G, 1998. [Geochemiczne klasy czystości osadów wodnych].[Article in Polish]. Przeg. Geol. 46:49-54.

Bojakowska I, Gliwicz T, Kucharzyk J, 2014. The relationship between the content of zinc and major elements in lake sediments in Poland. Environ. Protect. Nat. Res. 25: 17-23.

Boyle JF, 2000. Rapid elemental analysis of sediment samples by isotope source XRF. J. Paleolimnol. 23:213-221.

Burton GA Jr, 2002. Sediment quality criteria in use around the world. Limnology 3:65 -75.

Calanchi N, Dinelli E, Lucchini F, Mordenti A, 1996. Chemostratigraphy of late Quaternary sediments from Lake Albano and Adriatic Sea Cores (PALICLAS Project). Mem. Ist. Ital. Idrobiol. 55:247-263.

Chabbi A, 2003. Metal concentrations in pore water of the Lusatian lignite mining sediments and internal metal distribution in Juncus bulbosus. In: A. Chabbi, R.F. Hüttl (eds.), Biological and chemical perspectives of ecosystem disturbance. Wat. Air Soil Poll. 3:105-117.

Contaminated Sediment Standing Team, 2003. Consensus-based sediment quality guideline. Recommendations for use and application. Interim guidance. Wisconsin Department of Natural Resources. Available from: http://dnr.wi.gov/topic/ ${ }^{\circ}$ brownfields/documents/ cbsqg_interim_final.pdf

Das BK, Haake B-G, 2003. Geochemistry of Rewalsar Lake sediment, Lesser Himalaya, India: implications for sourcearea weathering, provenance and tectonic setting. Geosci. J. 7:299-312.

Davison W, 1993. Iron and manganese in lakes. Earth-Sci. Rev. 34: 19-163.
Domagalski JL, Eugster HP, Jones BF, 1990. Trace metal geochemistry of Walker, Mono, and Great Salt Lakes, p. 315353. In: R.J. Spencer and I.M. Chou (eds.) Fluid-mineral interaction: a tribute to H.P. Eugster. The Geochem Society, Special Publ. 2.

Duzgoren-Aydin NS, 2007. Sources and characteristics of lead pollution in the urban environment of Guangzhou. Sci. Total Environ. 385:182-195.

El-Sayed SA, Moussa EMM, El-Sabagh MEI, 2015. Evaluation of heavy metal content in Qaroun Lake, El-Fayoum, Egypt. Part I: Bottom sediments. J. Rad. Res. Appl. Sci. 8:276-285.

European Commission, 2000. Directive 2000/60 of the European Parliament and the Council of 23 October 2000 establishing a framework for Community action in the field of water policy. Official J. Eur. Union L327, pp. 1-72.

Farooqui A, Bajpai U, 2003. Biogenic arsenopyrite in holocene peat sediment, India - Ecotox. Environ. Safe. 55:157-161.

Gensemer RW, Playle RC, 1999. The bioavailability and toxicity of aluminum in aquatic environments. Crit. Rev. in Environ. Sci. Technol. 29:315-450.

Głosińska G, Siepak J, 2006. [Metale ciężkie w obszarze równin zalewowych].[Article in Polish]. Ekologia 3:36-39.

Goher ME, Farhet HI, Abdo M, Salem SG, 2014. Metal pollution assessment in the surface sediment of Lake Nasser, Egypt. Egypt. J. Aquat. Res. 40:213-224.

Håkanson L, 1980. Ecological risk index for aquatic pollution control. A sedimentological approach. Wat. Res. 14: 975-1001.

Haley SM, Tappin·AD, Bond PR, Fitzsimons MF, 2006. A comparison of SEM-EDS with ICP-AES for the quantitative elemental determination of estuarine particles. Environ. Chem. Lett. 4:235-238.

Harmsen J, 2007. Measuring bioavailability: from a scientific approach to standard methods. J. Environ. Qual. 36:1420-1428.

Juśkiewicz W, Marszelewski W, Tylmann W, 2015. Differentiation of the concentration of heavy. metal and persistent organic pollutants in lake sediments depending on the catchment management (Lake Gopło case study). Bull. Geog. 8:71-80.

Kabata-Pendias A, 2004. Soil-plant transfer of trace elements an environmental issue. Geoderma 122:143-149.

Kabata-Pendias A, Pendias H, 2001. Trace elements in soils. 3rd ed. CRC Press, Boca Raton: 331 pp.

Kennedy RH, Cooke GD, 1982. Control of lake phosphorus with aluminum sulphate - dose determination and application techniques. War. Resour. Bull. 18 389-395.

Kumar SP, Patterson Edward JK, 2009. Assessment of metal concentration in the sediment cores of Manakudy estuary, south west coast of India. Ind. J. Mar. Sci. 38:235-248.

LAWA, 1998. [Länder-Arbeitsgemeinschaft Wasser. Beurteilung der Wasserbeschaffenheit von Fließgewässern in der Bundesrepublik Deutschland - chemische Gewässergüteklassifikation, Zielvorgaben zum Schutz oberirdischer Binnengewässer]. [Publication in German]. Band 2, Berlin.

Leopold EN, Baussand P, Emmanuel EG, 2012. Heavy metals accumulation in sediment cores of the Municipal Lake of Yaounde, Cameroon. Glob. J. Eviron. Res. 6:100-110.

Lepane V, Varvas M, Viitak A, Alliksaar T, Heinsalu A, 2007. Sedimentary record of heavy metals in Lake Rouge Liinjarv, southern Estonia. Eston. J. Earth Sci. 56:221-232. 
Lewander M, Greger M, Kautsky L, Szarek E, 1996. Macrophytes as indicators of bioavailable $\mathrm{Cd}, \mathrm{Pb}$ and $\mathrm{Zn}$ flow in the river Przemsza, Katowice Region. Appl. Geochem. 11:169-173.

Li X, Poon CS, Liu PS, 2001. Heavy metal contamination of urban soils and street dusts in Hong Kong. Appl. Geochem. 16:1361-1368.

Lindsay W, Norvell W, 1978. Development of a DTPA soil test for zinc, iron, manganese, and copper. Soil Sci. Soc. Am. J. 42:421-428.

Macdonald DD, Ingersoll CD, Berger TA, 2000. Development and evaluation of consensus-based sediment quality guidelines for freshwater ecosystems. Arch. Environ. Contam. Toxicol. 39:20-31.

Mahjoor AS, Karimi M, Rastegarlari A, 2009. Mineralogical and geochemical characteristics of clay deposits from South Abarkouh District of clay deposit (Central Iran) and their applications. J. Appl. Sci. 9:601-614.

Markowski S, 1980. [Struktura i właściwości podtorfowych osadów jeziornych rozprzestrzenionych na Pomorzu Zachodnim jako podstawa ich rozpoznawania i klasyfikacji], p. 44-55. [Article in Polish]. In: Proceedings Conference "Kreda jeziorna i gytie". PTPNoZ Gorzów Wielkpolski, Zielona Góra.

Mudroch A, 1993. Lake Ontario sediments in monitoring pollution. Environ. Monit. Assess. 28:117-129.

Müller G, 1969. Index of geo-accumulation in sediments of the. Rhine River. Geojournal 2:108-118.

Naeher S, Gilli A, North RP, Hamann Y, Schubert CJ, 2013. Tracing bottom water oxygenation with sedimentary $\mathrm{Mn} / \mathrm{Fe}$ ratios in Lake Zurich, Switzerland. Chem. Geol. 352: 125-133.

Nealson KH, Saffarini D, 1994. Iron and manganese in anaerobic respiration - environmental significance, physiology, and regulation. Ann. Rev. Microbiol. 48:311-343.

Njogu PM, Keriko JM, Wanjau RN, Kitetu JJ, 2011. Distribution of Heavy metals in various lake matrices; water, soil, fish and sediments: a case study of the Lake Naivasha basin, Kenya. J. Agricul. Sci. Tech. 13:91-103.

Ntakirutimana T, Du G, Guo J-S, Gao X, Huang L, 2013. Pollution and potential ecological risk assessment of heavy metals in a lake. Pol. J. Environ. Stud. 22:1129-1134.

Öztürk M, Özözen G, Minareci O, Minareci E, 2009. Determination of heavy metals in fish, water and sediments of Avsar Dam Lake in Turkey. Iran. J. Environ. Health. Sci. Eng. 6:73-80.

Poté J, Haller L, Loizeau JL, Bravo AG, Sastre V, Wildi W, 2008. Effects of sewage treatment plant outlet pipe extension on the distribution of contaminants in the sediments of the Bay of Vidy, Lake Geneva, Switzerland. Biores. Technol. 99: 7122-7131.

Rabajczyk A, Jóźwiak MA, Jóźwiak M, Kozłowski R, 2011. Heavy metals $(\mathrm{Cd}, \mathrm{Pb}, \mathrm{Cu}, \mathrm{Zn}, \mathrm{Cr})$ in bottom sediments and the recultivation of Kielce Lake. Pol. J. Environ. Stud. 20: 1013-1019.

Rabee AM, Al-Fatlawy YF, Najim Abd Own A-A-H, Nameer M, 2011. Using Pollution Load Index (PLI) and Geoaccumulation Index (I-Geo) for the assessment of heavy metals pollution in Tigris River sediment in Baghdad Region. J. AlNahrain Univ. 14:108-114.

Reimann C, de Caritat P, 2005. Distinguishing between natural and anthropogenic sources for elements in the environment: regional geochemical surveys versus enrichment factors. Sci. Total Environ. 337:91-107.

Reitzel K, Hansen J, Andersen FO, Hansen KS, Jensen HS, 2005. Lake restoration by dosing aluminum relative to mobile phosphorus in the sediment. Environ. Sci. Technol. 39:4134-4140.

Reitzel K, Jensen HS, Egemose S, 2013. pH dependent dissolution of sediment aluminum in six Danish lakes treated with aluminum. Wat. Res. 47:1409-1420.

Reitzel K, Jensen HS, Flindt M, Andersen FO, 2009. Identification of dissolved nonreactive phosphorus in freshwater by precipitation with aluminum and subsequent P-31 NMR analysis. Environ. Sci. Technol. 43:5391-5397.

Rollinson HR, 1993. Using geochemical data: Evaluation, presentation, interpretation. Longman, New York: 352 pp.

Sanei H, Goodarzi F, Outridge PM, 2010. Spatial distribution of mercury and other trace elements in recent lake sediments from central Alberta, Canada: An assessment of the regional impact of coal-fired power plants. Int. J. Coal Geol. 82:105-115.

Sezgin N, Ozcan HK, Demir G, Nemlioglu S, Bayat C, 2003. Determination of heavy metal concentrations in street dusts in Istanbul E-5 highway. Environ. Int. 29:979-985.

Solecki J, Chibowski S, 2000. Examination of trace amounts of some heavy metals in bottom sediments of selected lakes of south-eastern Poland. Pol. J. Environ. Stud. 9:203-208.

Szymanowska A, Samecka-Cymerman A, Kempers AJ, 1999. Environmental research, Section B. Heavy metals in three lakes in West Poland. Ecotoxicol. Environ. Saf. 43:21-29.

Tang W, Shan B, Zhang H, Zhang W, Zhao Y, Ding Y, Rong N, Zhy X, 2014. Heavy metal contamination in the surface sediment of representative limnetic ecosystems in China. Sci. Rep. 4:7152.

Taylor SR, McLennan SM, 1985. The continental crust: its composition and evolution. Blackwell Scientific Publication, Carlton: 312 pp.

Tokalioğlu S, Kartal S, Elçi L, 2000. Determination of heavy metals and their speciation in lake sediments by flame atomic absorption spectrometry after a four-stage sequential procedure. Anal. Chim. Acta 413:33-40.

Tylmann W, 2004. Heavy metals in recent lake sediments as an indicator of $20^{\text {th }}$ century pollution: Case study on lake Jesień. Limnol. Rev. 4:261-268.

Tylmann W, Łysek K, Kinder M, Pempkowiak J, 2011. Regional pattern of heavy metal content in lake sediments in Northeastern Poland. Water Air Pollut. 216:217-228.

Vrhovnik P, Dolenec T, Serafimovski T, Dolenec M, Šmuc NR, 2013. The occurrence of heavy metals and metalloids in surficial lake sediments before and after a tailings dam failure. Pol. J. Environ. Stud. 22:1525-1538.

Warren CJ, Drimmie RJ, Kanters WA, Frape SK, 1996. Clay mineralogy of Lake Ontario sediments. J. Great Lakes Res. 22:864-870.

Wetzel RG, 1983. Limnology. 2nd ed. Saunders College Publishing, Philadelphia: 859 pp.

Zhang Q, Wang L, Zhao L, Sun H, Lu Y, 2012. Analysis and assessment of heavy metal pollution in sediments of Tianjin Harbour and Dagu Drainage Canal in Bohai Bay, China. Fresen. Environ. Bull. 21:1777-1785. 